\title{
Japan under pressure
}

\section{Tokyo}

JAPAN'S fishermen are coming under increasing international pressure to end their use of massive drift nets on the high seas. At last week's summit in Kuala Lumpur, Commonwealth nations joined the growing chorus of countries calling for an international ban on pelagic drift-net fishing, which critics liken to 'stripmining' the ocean.

Made of fine, nylon monofilament, drift nets can stretch across nearly $60 \mathrm{~km}$ of ocean and snare most fish which encounter its virtually invisible mesh to a depth of 15 metres. Designed primarily to catch squid, salmon and young tuna, drift nets are being blamed by environmentalists for the indiscriminate slaughter each year of an estimated 1 million sea birds and 200,000 marine mammals, in particular dolphins and porpoises.

New Zealand, alarmed by the possibility that Japanese and Taiwanese driftnet fleets could wipe out the South Pacific's albacore tuna fishery within the next few years, is putting the finishing touches to a resolution it will submit to the United Nations for a ban on high seas drift nets.

The United States, concerned over the 'piracy' each year of some million migrating North American salmon and steelhand trout by drift-net fleets fishing in international waters of the North Pacific, is expected to co-sponsor the resolution.

Japan, which operates 500 of the 1,300 Asian drift-net vessels known to ply the Pacific, feels talk of a ban is premature and that drift nets should be regulated as part of a comprehensive management scheme covering all fishing practices in the Pacific. With an estimated 8,000 jobs and some $\$ 1,300$ million in revenue at stake, Japan is hardly ready to give up without a fight on the issue. "We cannot accept such a radical and unilateral measure to stop our operators without more objective scientific data", said Minoru Morimoto, an official at Japan's Fisheries Agency.

By the time more conclusive data on the impact of drift nets are made available, however, it could be too late to save the South Pacific albacore fishery, according to the Forum Fisheries Agency (FFA), which represents 15 island nations in the region.

The FFA estimates the maximum sustainable catch for the entire tuna surface fishery in the region at around 10,000 tons per year, the amount caught by Japan's drift-net fleet after it expanded in size from 20 boats in the 1987-88 winter fishing season to 60 boats last year. The influx of Japanese drift-net vessels was in part spurred by rising prices for albacore and a decision by the United States last year to bar Japanese from fishing in its 200-mile exclusive economic zone.
"Since young albacore are destined for the cannery, Japanese just try to catch as much as they can without waiting for the fish to reach full size", said an official at the New Zealand Embassy in Tokyo. "This gluts the market, drives prices down and forces them to catch more. It's a vicious circle."

The region's longline fishermen, who make their living off more valuable adult albacore which generally swim at greater depth than young tuna, are already reporting a decline in the size of their catch.

If the albacore fishery is destroyed by drift-netters, an important chance for the economic development of the region may also be lost. "If the albacore fishery isn't managed properly", says Fiji's ambassador to Tokyo, Charles Walker, "we could end up with ghost towns in the South Pacific."
While continuing to defend the use of drift nets, the Japanese government has ordered a two-thirds reduction of the South Pacific drift-net fleet for the forthcoming season. Japan has also agreed to allow a scientific observer appointed by the region to accompany a research vessel to the South Pacific this year. The Taiwanese have not yet responded to calls for a ban.

Japan has further agreed to allow the United States to track some 200 Japanese squid drift-net boats with transponders starting next June and increase scientific observations of the fleet in the mid- and North Pacific.

"Up until now, there has been little or no global management of fisheries, resources and its become a matter of urgency - regardless of whether there's drift-net fishing", concludes a US government fisheries expert. "We're entering a new era involving delicate issues of sovereignty and financial responsibility. It's not going to be easy." Mike Shaitz

\section{Dupont battles with Cetus}

\section{Washington}

A BATTLE over the lucrative market for the widely used DNA amplification technique PCR (polymerase chain reaction) has set the US biomedical research community buzzing. When Dupont announced in August a challenge to the PCR patents owned by Cetus (see Nature 341, 418; 1989) it would at first give no details of the basis for the case. But Dupont's patent attorney, George Frank, now says that the company has unearthed two scientific papers describing the technique which were published more than 10 years before the research for which Cetus won its patents.

The first, a paper by $\mathrm{H}$. Gobind Khorana and colleagues published in the Journal of Molecular Biology in 1971, describes in principle a technique that can be used to synthesize multiple copies of genes, and finishes by saying that "experiments based on these lines of thought are in progress" (see Nature 341, $570 ; 1989$ ). In a subsequent paper published in 1974 in the Journal of Biological Chemistry, Khorana and Amos Panet briefly describe unpublished research from the same laboratory in which multiple copies of DNA sequences were obtained by alternate cycles of heating and cooling in the presence of primers, techniques also used in the Cetus method. Frank claims that either of these alone is sufficient to invalidate Cetus's patent, because under US patent law a patent cannot be granted if a description of the invention was published more than one year before the patent application was filed.

But the general counsel for Cetus,
Michael Ostrach, says that although the company was not aware of these papers when it filed for its patent in 1985, they will not affect the validity of Cetus's patents because they do not "teach" the reader how to perform PCR: to permit a patent to be granted, a technique must be described in sufficient detail to enable others to replicate it. If the earlier papers had described PCR, Ostrach says, researchers would have started using the technique then, instead of waiting until 1985, when the research done at Cetus was published. Frank counters that the technique was not practical in the 1970 s because it was difficult to obtain primers, an explanation that Ostrach rejects.

Meanwhile, Du Pont says that it is making "substantial investments" in the development of DNA replication and detection kits for sale to researchers and that commercial distribution may begin this month. It also plans to sell thermocyclers, the instruments which automate the PCR process, and to sell PCR-based products for the diagnosis of human diseases, although Cetus representatives have told Dupont that it will not be granted a licence for diagnostic products. Dupont admits to being "in reasonable apprehension that it will be sued by Cetus" for patent infringement

The case is likely to come to court in about a year, according to Frank, and both sides say they will have expert witnesses to support their cases. If the challenge is upheld, it will be "a cataclysmic event" for Cetus, according to Robert Cooper, a biotechnology analyst at Kidder-Peabody.
Christine McGourty 